\title{
NATO-EU COOPERATION
}

\author{
Eduard SIMION
}

\section{SACTREPEUR NATO HQ, Romania simion_edi@yahoo.com}

\begin{abstract}
The current security situation is marked an increasing competition for power at global scale, the use of power politics, and the growth of the influence of the non-state actors in a changed resource and demographic landscape. NATO and EU seem to be out of sync with the developments in the world, situation which puts their very existence into questioning. However, a closer look shows that both organisations have displayed a very high degree of versatility, re-inventing themselves to adapt to the changing environment, and surviving all the evolution so far, while other peer organisations have become history. Therefore, the main question is whether NATO and EU will overcome the existing and future challenges and continue the current positive trend in their cooperation? When considering the common history, the trend and the most recent evolutions, one can only draw a positive answer. The most significant areas of recent cooperation which indicate a definite positive trend are the adaptation of the NATO Command Structure, the development of military capabilities, and the definition of the cyberspace as an operational domain.
\end{abstract}

\section{Keywords: NATO, EU, cooperation, defence, capabilities}

\section{Introduction}

The North Atlantic Treaty Organisation (NATO) and the European Union (EU) are essentially two different institutional constructs: while NATO has always been an exclusively military alliance - albeit governed by a political decision-making body, the EU started as a purely economic organisation which expanded gradually its competencies, with this spill-over eventually reaching areas such as security and defence. But however different, the two organisations are formed around the respect of the same fundamental values of freedom, security and prosperity of the societal models they represent. And this should not come as a surprise, considering that the large majority of the states forming the two organisations are in the same time NATO Allies and EU partners [1]. Moreover, most of the countries belonging to only one of the two organisations (e.g. USA, Canada, and Norway as NATO but non-EU; or
Austria, Finland, Ireland, Sweden as EU, but non-NATO) are old liberal democracies who share strong historical, political and military ties with the other members, forming together what is commonly referred to as the "Western World" or "the free world". Therefore, it can be said that NATO and EU have common strategic interests, and that, in consequence, they "were doomed" to cooperate from the very beginning.

To support this statement stands the reason for the birth of each of the two organisations, which was very much one and the same: to avoid future wars. The founding NATO nations conceived that by putting together their defences under the famous "all for one and one for all" Article $\mathrm{V}$ of the Washington Treaty. In their turn, the founding nations of the Coal and Steel Community - and which was to become the EU - pursued the same purpose by putting 
together the prime materiel for their defence industries.

But despite all the above, during the early days cooperation between NATO and EU was not very formal, nor was it very visible. Indeed, it comes obvious now that EU couldn't grow to become the model of economic success of the present without the military shield provided by NATO. In return, it can be stated with a fair degree of confidence that in the absence of the persistent economic growth and the space of freedom and justice created by the EU, NATO could have had a different development over time. Yet again, during the days of the Cold War the links between the two organisations were more incidental, the works and the progress of one benefiting and encouraging the works and the progress of the other, but without any evident coordination amongst them.

Shortly after the fall of the Berlin Wall and the dissolution of the Soviet Union, the relationships between EU and NATO begun to change by getting a materiel form. It all started when the EU concluded the Maastricht Treaty in 1992 which, by creating a Common Foreign and Security Policy (CFSP) framed on intergovernmental relations, also laid the basis of the Common Security and Defence Policy (CSDP). In practice this defence component of the EU was seen as the strengthening of the European pillar of NATO, meant to cover the softer package of the "Petersberg tasks[2]". The idea was further developed when, in 1996, NATO agreed to make available its assets for EUled crisis management operations, under the "Berlin Plus" agreement.

The developments in policy were consolidated at inter-institutional levels, with the North Atlantic Council having the first formal meeting with the EU Political and Security Committee in September 2000, followed by the first formal meeting between NATO and EU at Foreign Ministers level, in May 2001. Cooperation between NATO and EU continued to deepen with the creation of the NATO-EU
Capability Group (following the creation in 2004 of the European Defence Agency), the enforcement of an agreement on the security of information exchange, the establishment of a NATO Permanent Liaison Team at the EU Military Staff and of an EU Cell at the NATO Supreme Headquarters Allied Powers Europe. In this respect it is also important to mention the significant level of cooperation achieved in the field, with EU taking over from NATO the operations in the Former Yugoslav Republic of Macedonia and Bosnia and Hercegovina.

The result was that NATO and the EU started to meet regularly at different levels to discuss and agree upon issues of common interest, to include the deepening of the ties between the two organisations and the development of new fields of collaboration.

\section{A new framework for cooperation}

In July 2016 in Warsaw, the relationship between NATO and the EU was taken to a whole new level. In a Joint Declaration signed in the margins of the NATO Summit, NATO Secretary General Jens Stoltenberg, the President of the European Council Donald Tusk, and the President of the European Commission Jean-Claude Juncker pledged to boost cooperation between the two organisations. Capitalising on the decisions taken at the highest levels of the two organisations, the EU and NATO ministers endorsed in December 2016, in a coordinated manner, a concrete package of 42 concrete measures to put in practice the Joint Declaration. These measures covered seven areas of cooperation [3] and included: bolstering resilience to hybrid threats, ranging from disinformation campaigns to acute crises; enhancing the cooperation between NATO's Operation Sea Guardian and the EUNAVFOR Operation Sophia in the Mediterranean Sea; improving the exchange of information on cyber threats and the sharing of best practices on cyber security; ensuring the coherence and complementarity of each other's defence 
planning processes; conducting parallel and coordinated exercises, including join decision-making at highest levels; support local capacities of partner countries in the sectors of security and defence.

The NATO Secretary General and the EU High Representative for Foreign Affairs and Security started to report regularly to NATO Allies and EU Member States with regards to the status and the development of this cooperation, and their 2017 conclusions indicated considerable progress. As a result, in December 2017, NATO and EU ministers agreed to expand NATO-EU cooperation with a set of 34 new measures, to include the improving of the mobility of military forces, coordinating counterterrorism support and promoting the role of women in peace and security.

NATO and the EU continued to hold regular political consultations on security issues in Europe and its neighbourhood. When the crisis in Ukraine emerged, both organizations started to work together in order to make sure that their actions are coherent and that they supplement each other, especially with regards to the effectiveness of the sanctions imposed to Russia. But consultations the two organisations have also covered the Western Balkans, Libya and the Middle East. As it has already been mentioned in the previous section, NATO and the EU have long cooperated in crisis management and operations, in particular in the Western Balkans. In Kosovo, the NATO peacekeeping force KFOR works closely in the field with the EU's Rule of Law Mission in Kosovo (EULEX) and the EU's Operation EUFOR Althea in Bosnia and Herzegovina was, and still is commanded by the NATO Deputy Supreme Allied Commander Europe, located at the Supreme Headquarters Allied Powers Europe (SHAPE).

But this operational cooperation also included Afghanistan, the NATO-led "Resolute Support" Mission and its predecessor, the International Security Assistance Force (ISAF), having close cooperation with the EU's Rule of Law Mission (EUPOL).

In more recent years, cooperation between NATO and EU has extended to maritime security, as NATO and EU naval forces joined their efforts in response to the refugee and migrant crisis. NATO has deployed a standing maritime force to the Aegean Sea to conduct reconnaissance, monitoring and surveillance of illegal crossings, thus providing direct support to the Greek - but also to the Turkish authorities - and the EU. In Central Mediterranean Sea, NATO's Operation "Sea Guardian" continues to support EU Operation Sophia with information and logistics.

One of the new areas of cooperation opened by the 2016 Joint Declaration was that of defence capability development. NATO and EU continue to improve their coordination in order to avoid unwanted competition and to continue to develop complementary sets of capabilities that allow the two organizations to accomplish their core tasks more effectively, to provide security in Europe and to project stability worldwide. Experts from the European Defence Agency (EDA) and NATO work together in order to address common capability shortfalls, using existing development processes.

The Cyber dimension has emerged as one of the most important new areas for defence, with NATO recognising it as its fourth domain of operations, together with land, air and maritime domains. To respond to the new developments in this field, NATO and EU cyber incident response teams established permanent mechanisms for exchanging policy updates and best practices. A very good example of successful coordination was the joint response capacity displayed by NATO and EU cyber elements during the WannaCry and NotPetya attacks.

Last, but not least, the two organizations are making efforts to put in place concrete measures to increase their situational awareness, which is aimed to contribute to 
their response to hybrid threats. In this respect, NATO and the EU benefit from and contribute jointly to the newly established European Centre on Hybrid Threats in Finland. Also, the NATO Secretary General was invited to CYBRID, an EU hybrid exercise in Estonia, while EU representatives took part in NATO's annual CMX exercise, as well as the Cyber Coalition exercise.

\section{What to expect next}

There are many sceptics who believe that, since the Cold War NATO became nothing more than an empty shell, and that EU, once it crossed over from being a purely economic organisation featuring a customs union into becoming a political supranational body, has overstretched its capacities. And indeed, there are many arguments in favour of these critics: NATO is only a shadow of the military power it represented at the peak of the Cold War, with its "raison d'etre" being questioned over and over again, last time famously by the newly elected President of the United States of America; from its side, EU started to suffer a series of heavy blows once it exceeded its economical nature and aimed for a Constitution, a common currency, integrated immigration policies etc.

On the other side of the balance stay the relatively long history of success of both organisations. EU has got an impetus of its own, and despite - and maybe even against - the recent centripetal forces which seem to push it towards implosion, it seems to become more robust and mature. As for NATO, which has been called repeatedly "the most successful military alliance in human history", it is very improbable that it has reached its end. Quite on the contrary, considering the events triggered by the annexation of Crimea by Russia (and adding here the latest scandal triggered by the attack with the neurotoxin Novichok on the former Russian spy Serghei Skripal and his daughter; and the re-election of Putin, which means that in the foreseeable future Russia will continue its ascend to filling-in the space left by the fall of USSR), we may actually speak of a rejuvenation of NATO. And, the fact that the two super-institutions join powers and put their interests together, can only bring good news to those who believe in the future of NATO and EU.

\section{References}

[1] 22 out of 29 NATO members, respectively 28 EU members, are part of both organisations

[2] The Petersberg tasks are: humanitarian search and rescue (SAR); crisis management; peacekeeping; environmental protection

[3] The seven areas of cooperation between NATO and EU decided by the defence ministers in December 2016, are: 1. countering hybrid threats; 2.operational cooperation including maritime issues; 3.cyber security and defence; 4.defence capabilities; 5.parallel and coordinated exercises and defence; 6. defence industry and research; and 7.security capacity-building 